\title{
In Vitro Inhibition of Pseudomonas aeruginosa Adhesion by Xylitol
}

\author{
Letícia Pinheiro de Sousa ${ }^{1}$, Annelisa Farah da Silva ${ }^{1}$, Natalia Oliveira Calil ${ }^{1}$, Murilo Gomes \\ Oliveira $^{1}$, Silvio Silvério da Silva ${ }^{2}$ and Nádia Rezende Barbosa Raposo ${ }^{1,3^{*}}$ \\ ${ }^{1}$ Faculdade de Farmácia; Universidade Federal de Juiz de Fora; 36036-330; Juiz de Fora - MG - Brasil. \\ ${ }^{2}$ Departamento de Biotecnologia; Escola de Engenharia de Lorena; Universidade de São Paulo; Estrada do \\ Campinho, s/n, C.P.: 116; 12602-810; Lorena - SP - Brasil. ${ }^{3}$ Laboratório de Neurociência; Departamento e \\ Instituto de Psiquiatria; Faculdade de Medicina; Universidade de São Paulo; São Paulo - SP - Brasil
}

\begin{abstract}
This study evaluated, in vitro, the antimicrobial activity and the anti-adherent property of xylitol (0.5, 2.5 and 5.0\%, $w / v)$ on two Pseudomonas aeruginosa strains (ATCC 9027 and clinical). The assay of antimicrobial activity was performed to determine a minimum inhibitory concentration (MIC) and the adhesion test was performed, by which the parameters regarding, growth in the culture medium, number of colony forming units (CFUs) released and slide evaluation by scanning electron microscopy (SEM) were analyzed. The Statistical Package for the Social Sciences (SPSS) was employed for statistical analysis. Results showed that xylitol had no antimicrobial activity on these strains; however, the inhibition of bacterial adherence was observed in microphotographs obtained by SEM. These results indicated that xylitol could be a future alternative to combat bacterial colonization.
\end{abstract}

Key words: Bacterial adhesion, Pseudomonas aeruginosa, Prevention and control, Xylitol

\section{INTRODUCTION}

Xylitol is a polyalcohol derived from xylose hydrogenation and considered nontoxic by the Food and Drug Administration (FDA). This compound has a molecular formula $\mathrm{C}_{5} \mathrm{H}_{12} \mathrm{O}_{5}$ $(1,2,3,4,5$ pentahydroxy pentane $)$ and appears as an odorless white crystalline powder (Mussatto and Roberto, 2002; Elias et al., 2006). Currently, xylitol's application has increased in the pharmaceutical, food industries, dental and clinical areas, being used as sweetener, excipient to pharmaceutical production, anticariogenic substance, osteoporosis combatant, acute otitis media and other pathologies (Mussatto and
Roberto, 2002; Berlinck and Lima, 2003; Pereira et al., 2009; Silva, 2010).

The pathogenic bacteria adherence hosting tissue is an essential process for these microorganisms' survival and colonization; it also represents a fundamental important stage in most infectious processes (Jankowska et al., 2008; Silva, 2010). In several cases, pathogenic bacteria adhesion is mediated by fimbriae which are present on the microorganism's surface and bind to carbohydrates on the host tissue surface (Sharon, 2006). Bacterial adhesion to the biomaterial surface is an essential step in the emergence of many infections. However, the material's physical structure and the molecular interactions

*Author for correspondence: nadiafox@gmail.com 
responsible for bacterial adhesion on these surfaces are still unknown (Katsikogianni and Missirlis, 2004).

A very promising approach, to research new biotechnological drugs, is based on the awareness of the microorganism's adherence on several surfaces and the mechanisms, which can prevent such colonization. There are some studies on the potential of xylitol for combating the bacterial biofilm formation, due to its anti-adherent property on some bacteria (Mussatto and Roberto, 2002; Pereira et al., 2009; Silva, 2010). However, no reports could be found on xylitol's action with Pseudomonas aeruginosa. Nowadays, this species great importance in the development of several pathologies is known, with great emphasis on hospital infections, whose traditional antimicrobials control is often difficult, due to the its significant resistance capacity (Nowakonski, 2007).

There are reports describing the anti-adherent property of xylitol for some bacteria. Sajjan et al. (2004) studied the use of xylitol to prevent the complex adherence of Burkholderia cepacia to respiratory tract epithelial cells. It was found that xylitol $(60-80 \mathrm{mg} / \mathrm{mL})$ inhibited this bacterial strain's growth by $65 \%$, and its absence was related to the success of lung transplants. Makinen (2000) reinforced xylitol's anticariogenic activity by studying newborns whose parents chewed gum containing xylitol. It was found that this action prevented the babies from developing caries, since aerosols from the mother would be the most common transmission way of Streptococcus mutans. This is possible because xylitol prevents bacterial adhesion on teeth, reducing the viable cell count and also the chance of transmission. Ferreira (2007) observed, through in vitro tests, that although the xylitol $(1.0,5.0$ and $10.0 \%)$ did not have any antimicrobial activity on the Staphylococcus aureus strain ATCC 25923, it presented an anti-adherent property on it.

Pseudomonas aeruginosa is a Gram-negative bacillus (which may appear as isolated rods or in pairs), aerobic, glucose non-fermenting and mobile through polar monotrichous flagellum. It is considered a clinically important opportunistic pathogen often related to hospital infections, because of its ability to survive for long periods adhered to surfaces, with minimum nutritional requirements and with high tolerance to environmental variations (Nowakonsky, 2007;
Mata and Abegg, 2007; Li et al., 2009). One of the main resistance mechanisms of $P$. aeruginosa is biofilm formation, which is an important factor in its persistence and dissemination. This bacterium also has a great ability to develop antimicrobial resistance besides being able to escape host defense mechanisms. It produces two types of protein adhesions (pilus and non-pilus) important in successfully colonizing abiotic surfaces and allowing its permanence in the host organism (Stehling, 1999; Iversen et al., 2008).

This study aimed to evaluate the antimicrobial activity and the anti-adherent property of xylitol on two $P$. aeruginosa strains.

\section{MATERIAL AND METHODS}

Xylitol with > 98\% purity was obtained from Fluka BioChemika, Switzerland. Two strains of Pseudomonas aeruginosa were used: (1) $P$. aeruginosa ATCC 9027, (2) a wild strain isolated from a hospitalized patient's catheter by the Clinical Analysis Laboratory of the University Hospital of the Federal University of Juiz de Fora (HU/UFJF), Minas Gerais, Brazil (clinical P. aeruginosa).

\section{Antimicrobial activity}

The microdilution technique in Mueller Hinton Broth (MHB) was used by which the minimum inhibitory concentration (MIC) was determined with turbidimetric analysis. The bacterial suspension of each strain was prepared with a sterile saline $(\mathrm{NaCl} 9.0 \mathrm{~g} / \mathrm{L})$ to a $25 \%$ transmission in the Libra S12 spectrophotometer (Biochrom, Denmark) and, thereafter it was subjected to serial dilutions with sterile saline. After a $24 \mathrm{~h}$ growth period, the colony forming units (CFUs) were counted in Tryptone Soy Agar (TSA), in order to obtain a $10^{3}-10^{4} \mathrm{CFU} / \mathrm{mL}$ standardized bacterial suspension.

For the negative control, $100 \mu \mathrm{L}$ of sterile MHB was used. The positive control consisted of $100 \mu \mathrm{L}$ of inoculated MHB with the standardized bacterial suspension $\left(10^{3}-10^{4} \mathrm{CFU} / \mathrm{mL}\right)$. In order to prepare the test-groups, $100 \mu \mathrm{L}$ of inoculated MHB and $100 \mu \mathrm{L}$ of xylitol in three concentrations $(0.5,2.5$ and $5.0 \%$, w/v) were used. At the same time, $100 \mu \mathrm{L}$ of these xylitol solutions were incubated with $100 \mu \mathrm{L}$ of sterile MHB for the purpose of controlling their sterility. To compare the MIC of 
xylitol to a reference antibiotic, incubation with inoculated $\mathrm{MHB}$ and $100 \mu \mathrm{L}$ of chloramphenicol $(0.025, \quad 0.25,2.5,25$ and $250 \mu \mathrm{g} / \mathrm{mL})$ was performed. All the assays were carried out in triplicate.

The microplate was incubated in an aerobic environment at $37^{\circ} \mathrm{C}$ for $24 \mathrm{~h}$. The minimum inhibitory concentration was determined through turbidity observation in the cultivation media after the incubation period. Finally, $200 \mu \mathrm{L}$ samples that showed no turbidity was incubated in $4 \mathrm{ml}$ of Tryptone Soy Broth (TSB) at $37^{\circ} \mathrm{C}$ for $24 \mathrm{~h}$ in order to determine if the antimicrobial action found was bacteriostatic (bacteria-inhibiting) or bactericidal (bacteria-killing). These procedures were conducted according to Candan et al. (2003).

\section{Anti-adherent property}

The colonies of each strain were resuspended in sterile saline and $200 \mu \mathrm{L}$ of these suspensions were transferred to $5 \mathrm{~mL}$ of TSB, which were incubated at $37^{\circ} \mathrm{C}$ for $24 \mathrm{~h}$. An aliquot of TSB with bacteria grown was diluted $1: 10 \quad(\mathrm{v} / \mathrm{v})$ with $0.1 \mathrm{M}$ phosphate buffer $(\mathrm{pH}$ 7.4). The volume of inoculum with the optical density $(\lambda=600 \mathrm{~nm})$ of 0.01 was calculated for each strain (Ferreira 2007; Silva, 2010).

In the test groups, the inoculum was added to 50 $\mathrm{mL}$ tubes, which contained $25 \mathrm{~mL}$ of TSB, a glass slide, and xylitol $(0.5,2.5$ and $5.0 \%)$. For negative controls, three conditions were used: 1) degreasing solution and slides, 2) slides and TSB, 3) only TSB. The positive control contained the bacterial suspension, TSB, slides and $5.0 \%$ glucose. All these systems were incubated at $37^{\circ} \mathrm{C}$ for $24 \mathrm{~h}$ (Ferreira 2007; Silva, 2010).

\section{Bacterial growth evaluation}

The bacterial suspensions contained in the tubes were inoculated in TSA and incubated at $37^{\circ} \mathrm{C}$ for $24 \mathrm{~h}$ for subsequent CFU counting (Ferreira et al., 2009; Silva, 2010).

\section{Bacterial growth evaluation after sonication}

The slides were removed and individually kept in the tubes. The slides were washed (two times) with $10 \mathrm{~mL}$ of $0.1 \mathrm{M}$ phosphate buffer ( $\mathrm{pH} 7.4)$, then $10.0 \mathrm{~mL}$ of the same buffer was added to the tubes, which were sonicated ( 2 cycles of $10 \mathrm{~min}$ ) at $40 \pm 6 \mathrm{kHz}$. Thereafter, dilution series were prepared with each solution after sonication $\left(10^{-2}\right.$ to $10^{-5}$ ), and they were inoculated on TSA plates and incubated at $37^{\circ} \mathrm{C}$ for $24 \mathrm{~h}$ in order to verify the colony's growth that had not adhered to the slides. The dilution that offered best counting conditions was used to achieve the experimental protocols (Locatelli et al., 2004; Ferreira et al., 2009; Silva, 2010).

Before the sonication and washing steps, the slides analyses by SEM were not performed because at this moment the test specimen remained full of proteins, carbohydrates and other compounds from the culture medium (visible to the naked eyes) which compromised the visualization of the colonies of $P$. aeruginosa by SEM.

\section{Slides evaluation by scanning electron microscopy (SEM)}

After sonication, the slides were again washed (two times) with $0.1 \mathrm{M}$ phosphate buffer ( $\mathrm{pH} 7.4$ ) and fixated with $1 \%$ glutaraldehyde for $12 \mathrm{~h}$. After this, the slides were washed (two times) with 0.1 M phosphate buffer ( $\mathrm{pH} 7.4$ ), dehydrated with increasing concentrations of ethanol (50 to 100\%) with an interval of 20 minutes between each exchange, and dried at room temperature. Finally, the slides were metalized in Balzers Union FL 9496 (Balzers, Germany) with $2 \mathrm{~nm}$ of gold for two minutes, and subsequently analyzed in the scanning electron microscope JSM 5310 (Jeol, Japan) at high vacuum in secondary electron mode (Locatelli et al., 2004; Ferreira et al., 2009; Silva, 2010).

\section{Statistical analysis}

The counting of CFU of both the bacterial suspensions in TSB and the solutions after sonication was performed in duplicate. The counting results of the colonies that had not adhered to the slides were expressed as mean \pm standard deviation $(n=2)$. Statistical analysis was performed by ANOVA, followed by Tukey's posthoc test to compare the group means. Correlation analysis between the concentration of xylitol and the number of cells detached was done by the parametric test of Pearson ( $p<0.05)$. The Statistical Package for the Social Sciences (SPSS) version 14.0 was employed for these calculations.

\section{RESULTS}

\section{Antimicrobial activity}

For both the strains, the three tested xylitol concentrations were not able to inhibit bacterial growth. Turbidity was only found in these tests 
and in the positive control. On the other hand, turbidity was not observed either in the negative control or in the xylitol solution sterility controls. The chloramphenicol tests showed the MIC $=25$ $\mu \mathrm{g} / \mathrm{mL}$ for the $P$. aeruginosa strain ATCC 9027 with bacteriostatic action. For the clinical $P$. aeruginosa strain, the MIC found was higher than $250 \mu \mathrm{g} / \mathrm{mL}$.

\section{Anti-adherent property}

Bacterial growth

An uncountable cell mass was observed in all the plates containing TSA culture medium and $1 \mathrm{~mL}$ of TSB bacterial suspension from each experimental treatment for both the strains. Cell growth was not observed only in the negative control (TSA), ensuring the processes' sterility.

\section{Bacterial detachment}

The quantitative result for the CFUs detached from the test specimen represented the number of bacilli not adhered to the slides, being an important reference in the anti-adherent property evaluation. A statistically significant difference was found among the number of CFUs detached by all the treatments $(p<0.05)$. The detached CFUs counted for both the strains is shown in Table 1. For the strain ATCC 9027, a high positive correlation $(r=$ 0.971) was found between the bacterial detachment and xylitol concentrations, which demonstrated the dose-dependence relation. However, this was not observed for the clinical strain for which a negative correlation was detected $(r=-0.922)$.

Table 1 - Bacterial detachment of Pseudomonas aeruginosa strains (ATCC 9027 and clinical) in experimental treatments.

\begin{tabular}{lcc}
\hline \multirow{2}{*}{ Treatments } & \multicolumn{2}{c}{ Bacterial Detachment $*^{\text {Pseudomonas aeruginosa }}$} \\
\cline { 2 - 3 } & $\begin{array}{c}\text { Clinical Pseudomonas aeruginosa } \\
\text { (dilution 10 }\end{array}$ \\
\hline Positive control )
\end{tabular}

*Results expressed as mean \pm standard deviation $(\mathrm{n}=2)$. Means followed by same letter differ by ANOVA followed by Tukey's post-hoc test $\left({ }^{\mathrm{a}, \mathrm{b}} \mathrm{p}<0.05\right)$.

\section{Bacterial adhesion}

In the negative control for both the strains, there were no particles with a similar shape and/or size to the bacterial cells (Figures $1 \mathrm{~A}$ and $2 \mathrm{~A}$, respectively), indicating that the applied test specimen treatment was appropriate. For the ATCC strain experiment, there were only significant amounts of adhered cells in the positive control (5.0\% glucose - Figure 1B), showing that the bacilli were, in fact, adhered in the test specimen (slides). However, no cells were found in the samples incubated with $0.5,2.5$ and $5.0 \%$ xylitol (Figures 1C, 1D and 1E, respectively). For the clinical strain, for positive control $(5.0 \%$ glucose - Figure 2B), adhered bacilli were found. Rare cells were observed in the treatments with $0.5,2.5$ and 5.0\% xylitol (Figures 2C, 2D and 2E, respectively). 

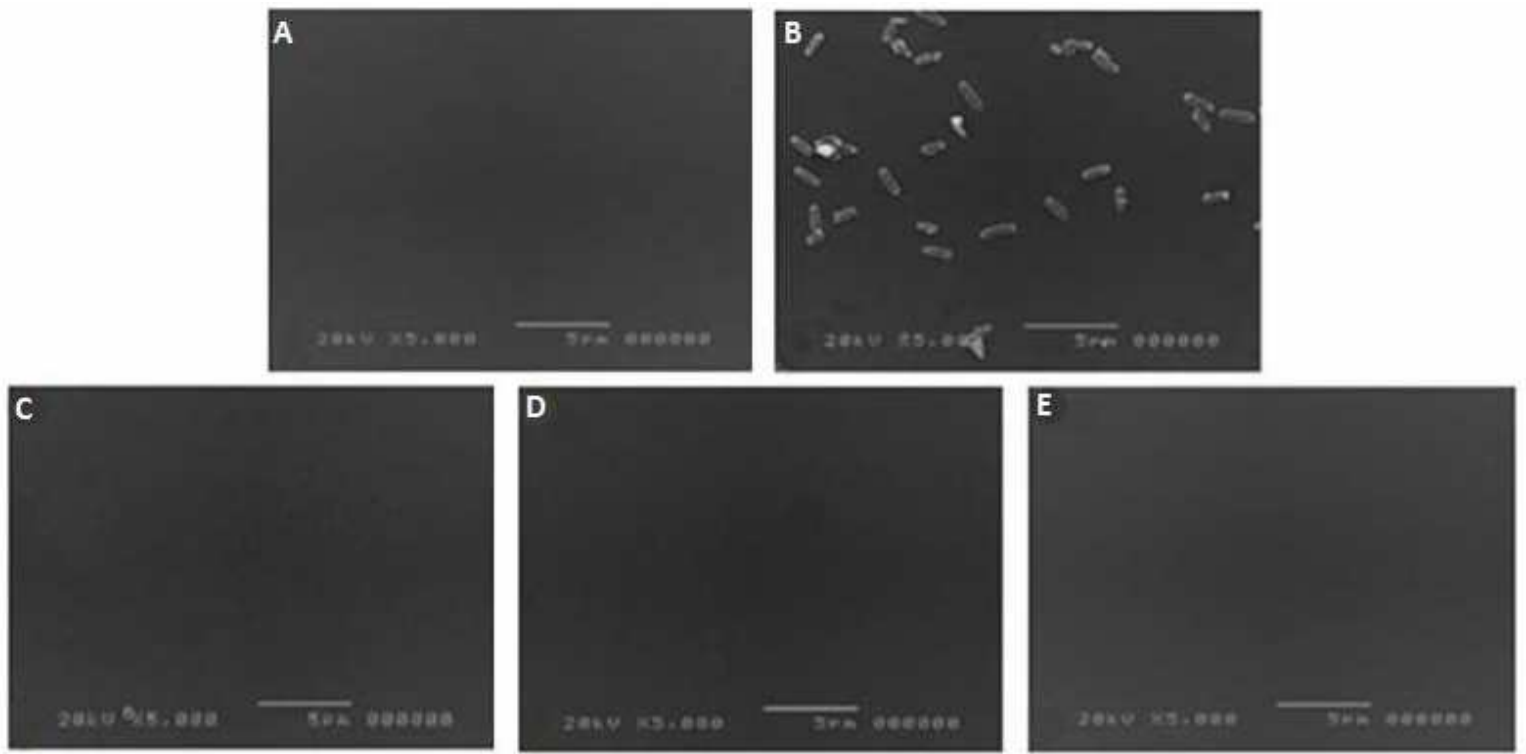

Figure 1 -SEM microphotographs of Pseudomonas aeruginosa strain ATCC 9027 in experimental treatments: A) negative control, B) positive control (5.0\% glucose), C) $0.5 \%$ xylitol, D) $2.5 \%$ xylitol and E ) $5.0 \%$ xylitol (bar $=5 \mu \mathrm{m})$.
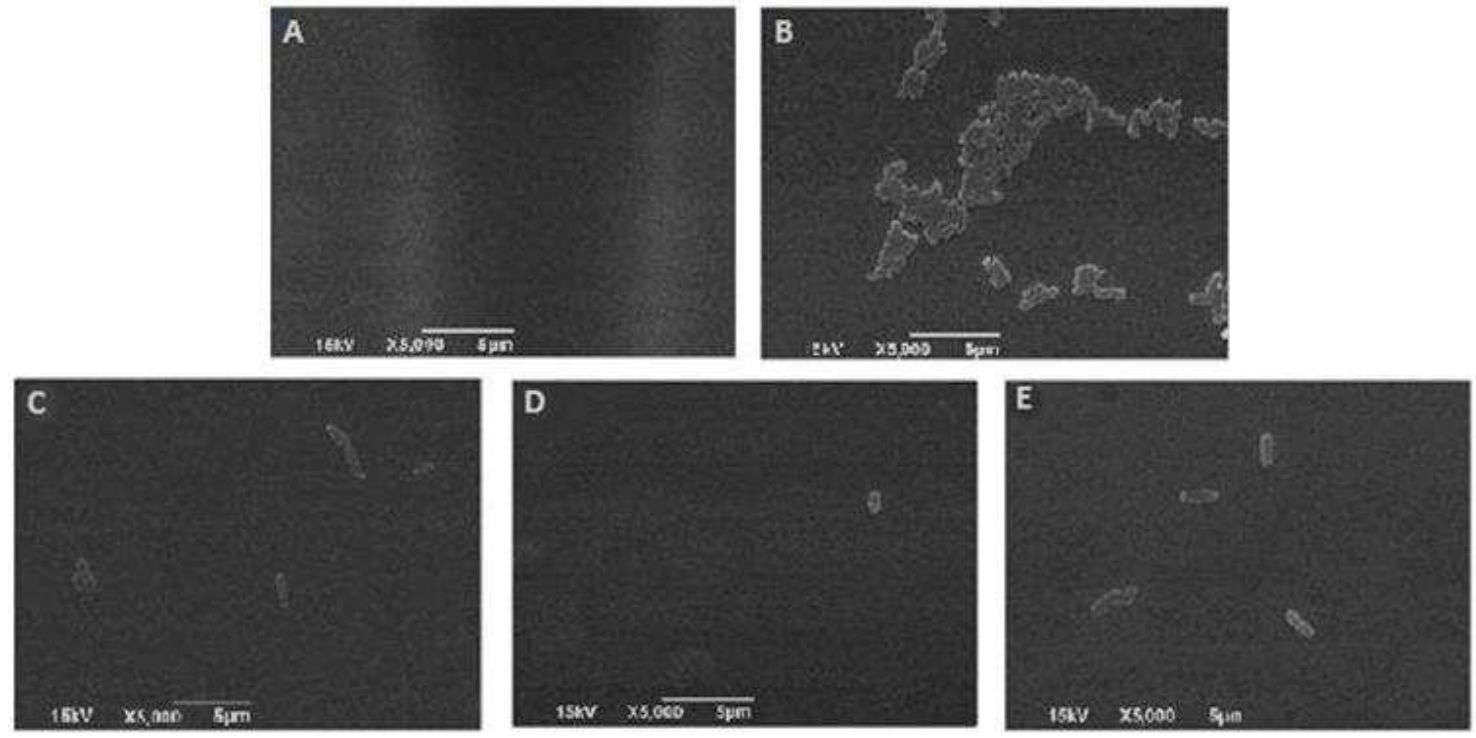

Figure 2 - SEM microphotographs of clinical Pseudomonas aeruginosa strain in experimental treatments: A) negative control, B) positive control (5.0\% glucose), C) $0.5 \%$ xylitol, D) $2.5 \%$ xylitol and E ) $5.0 \%$ xylitol (bar $=5 \mu \mathrm{m}$ ).

\section{DISCUSSION}

\section{Antimicrobial activity}

The antimicrobial activity tests revealed that none of the tested concentrations of xylitol $(0.5,2.5$ and $5.0 \%$ ) for both the strains inhibited the bacterial growth. These results corroborated with those obtained by Ferreira et al. (2009), who observed that xylitol did not show antimicrobial activity against the Staphylococcus aureus strain ATCC 25923. Silva (2010) found that xylitol was not able to inhibit the bacterial growth in different strains 
of Escherichia coli, Salmonella typhimurium and Shigella flexneri.

However, some other studies have demonstrated xylitol's antimicrobial activity. Tapiainem et al. (2001) considered xylitol responsible for inhibiting the $\alpha$-hemolytic Streptococcus growth, including Streptococcus pneumoniae, in the nasopharynx. Autio (2002) noted that preschool children who chewed gum sweetened with only xylitol (XyliFresh100\%, Hershey Food Corporation, U.S.A.) three times daily for three weeks had decreased salivary Streptococcus mutans in relation to children that did not use this chewing gum. Ly et al. (2008) showed that xylitol chewing gum consumption (11.7 $\mathrm{g}$ or $15.6 \mathrm{~g} /$ day) during six weeks, significantly reduced $(\mathrm{p}=0.0001)$ the Streptococcus mutans and Streptococcus sobrinus counts. The difference of turbidity in the chloramphenicol tests showed that the clinical strain, isolated from the hospitalized patient, had a greater resistance to the chloramphenicol antibiotic than the ATCC strain, confirming its higher pathogenic potential. The indiscriminate use of antimicrobials plays an important role in the resistant strain selections, and is probably the primordial cause of resistance, mainly observed in a hospital environment, where these drugs are more frequently used.

\section{Anti-adherent property \\ Bacterial growth}

The results were expected since the three xylitol concentrations tested in MIC did not prevent bacterial growth. However, bacterial growth was also evaluated in the adhesion test to ensure cell viability during the assay. Thus, these results confirmed that xylitol at tested concentrations had no bactericidal or bacteriostatic action on the two strains tested.

\section{Bacterial detachment}

For the strain ATCC 9027, the number of CFUs detached in the positive control (5.0\% glucose) was lower than the number of cells detached from the slides treated with xylitol, indicating its possible anti-adherent action. As expected, most of the bacilli should adhere to the slides treated with glucose, during the xylitol treatments, the bacilli were being detached. For the strain ATCC 9027, there was a dose-dependent relation since a positive correlation was found between the bacterial detachment and xylitol concentrations. Naaber et al. (1996) also found a dose-dependent inhibition of Clostridium difficile adherence to Caco- 2 cells, using 1.0, 5.0 and $10.0 \%$ xylitol. The authors were unaware of the action mechanism involved, but suggested it might occur in vivo in intestinal cells.

For the clinical strain, differently than expected, the number of bacilli detached from the slides treated with xylitol was lower than the detachment by the positive control (5.0\% glucose). This finding could be explained by the nutrients availability increase (with the supply of glucose) and, consequently, the bacterial multiplication increase, resulting in a high number of cells adhered to slides and in a high number of released cells. Due to this bacterial growth increase, it was not possible to count the CFUs in the dilution $10^{-3}$, making it necessary to count them in the dilution $10^{-5}$. Furlan and Castro (2001) and Silva et al. (2007) suggested that the presence of glucose in the culture medium improved the specific rates of microbial growth. The negative correlation between the bacterial detachment and xylitol concentrations indicated that there was no dosedependent relation.

\section{Bacterial adhesion}

Aiming to assess whether xylitol was capable or not of minimizing the tested strains adherence, the comparison between the slides exposed to xylitol and the positive control slide (with glucose) was considered, since some studies (Brassart et al., 1991; Ferreira, 2007; Silva, 2010) have described that the microorganism's adhesion mechanism was carbohydrate-dependent (Locatelli et al., 2004; Ferreira et al., 2009; Silva, 2010). For both the strains tested, the partial or total reduction of bacilli adhered to slides treated with xylitol, in comparison to the positive control (5.0\% glucose) slide, reinforced the anti-adherence idea of the studied compound.

The present results indicated that the basis of xylitol's action mechanism prevented the bacterial adherence. Ferreira et al. (2009) through SEM microphotographs, demonstrated the anti-adherent property of xylitol against Staphylococcus aureus strain ATCC 25923. Silva et al. (2010) observed, by both SEM and CFUs detached counts that xylitol $(0.5,2.5$ and $5.0 \%)$ was able to significantly inhibit the adherence of Shigella flexneri (ATCC 12022 and clinical) and clinical Salmonella enterica serotype Typhimurium. Ammons et al (2009) found that 5\% xylitol could prevent biofilm formation in vitro of a strain of 
$P$. aeruginosa isolated from clinical wounds. Kontiokari et al. (1998) evaluated the microorganism adherence in the presence of 5\% xylitol which prevented the Streptococcus pneumoniae adhesion, and, in a lesser proportion, the Haemophilus influenza adhesion. Söderling and Hietala-Lenkkeri (2010) found that $4 \%$ xylitol inhibited six oral streptococci strains adhesion to glass, which indicated that xylitol could contribute to decreased plaque accumulation. Silva et al. (2011) found xylitol $(0.5,2.5$ and 5.0\%) as a sugar inhibitor for the adhesion of two Escherichia coli bacterial strains (ATCC 8739 and clinical enteropathogenic Escherichia coli - EPEC).

New products studies, mainly of the biotechnological origin, have been directed in recent years in order to find preventive and corrective strategies for different diseases. All of this leads to the belief that xylitol could be a promising biomolecule, because it acts differently than traditional antibiotics by preventing the important microorganisms adherence to different surfaces. These results give xylitol a greater added value, since it reinforces its ability to inhibit the $P$. aeruginosa adherence. This new possibility of xylitol's use, especially in microbial colonization combat, strengthens this research line.

\section{ACKNOWLEDGMENTS}

The authors would like to thank CAPES for the scholarship and FAPEMIG for financial support. They would also like to thank Noêmia Rodrigues and Elivaldo Lima for technical assistance and Fundação André Tosello for the standard Pseudomonas aeruginosa strain donation.

\section{REFERENCES}

Ammons, M.C.B., Ward, L.S., Fisher, S.T., Wolcott, R.D. and James, G.A. (2009), In vitro susceptibility of established biofilms composed of a clinical wound isolated of Pseudomonas aeruginosa treated with lactoferrin and xylitol. Int J Antimicrob Agents, 33, 230-236.

Autio, J.T. (2002), Effect of xylitol chewing gum on salivary Streptooccus mutans in preschool children. ASDC J Dent Child, 69, 81-86.
Brassart, D., Woltz, A., Golliard, M. and Neeser, J.R. (1991), In vitro inhibition of adhesion of Candida albicans clinical isolates to human buccal epithelial cells by Fuc $\alpha 1 \rightarrow 2$ Gal $\beta$-bearing complex carbohydrates Infect. Immun., 59, 1605-1623.

Candan F., Unlu M., Tepe, B., Daferera, D., Polissiou, M., Sökmen, A. and Akpulat, A. (2003), Antioxidant and antimicrobial activity of essential oil and methanol extracts of Achillea millefolium subsp. millefolium Afan. (Asteraceae). J Ethnopharmacol, 87, 215-220.

Elias, F., Pinzan, A. and Bastos, J.R.M. (2006), Influência do complexo flúor-xilitol no controle da placa dentária e do sangramento gengival em pacientes herbiátricos com aparelho ortodôntico fixo. Rev. Dent. Press Ortodon. Ortop. Facial, 11,42-56.

Ferreira, A.S. (2007), Estudo de propriedades microbiológicas e toxicológicas do xilitol visando a sua aplicação no controle da dermatite atópica. MSc Dissertation, Engineering School of Lorena at University of São Paulo, Lorena - SP, Brazil.

Ferreira, A.S., Barbosa, N.R., Júnior, D.R. and Silva, S.S. (2009), In vitro mechanism of xylitol action against Staphylococcus aureus ATCC 25923. InCurrent Research Topics in Applied Microbiology and Microbial Biotechnology ed. Mendez-Vilas, A. Seville: World Scientific Publishing Co. Pte. Ltd, pp. 505-509.

Furlan, S.A. and Castro, H.F. (2001), Xylitol production by Candida parapsilosis under fed-batch culture. Braz Arch Biol Technol, 44, 125-128.

Iversen, B.G., Brantsaeter, A.B. and Aavitsland, P. (2008), Nationwide study of invasive Pseudomonas aeruginosa infection in Norway: Importance of underlying disease. J. Infect., 57, 139-146.

Jankowska, A., Laubitz, D., Antushevich, H., Zabielski, R. and Grzesiuk, E. (2008), Competition of Lactobacillus paracasei with Salmonella enterica for adhesion to Caco-2 cells. J. Biomed. Biotechnol., 2008, ID 357964, 6 pages.

Katsikogianni, M. and Missirlis, Y.F. (2004), Concise review of mechanisms of bacterial adhesion to biomaterials and of techniques used in estimating bacteria material interactions. Eur Cell Mater, 8, 3757.

Kontiokari, T., Uhari, M. and Koskela, M. (1998), Antiadhesive effects of xylitol on otopathogenic bacteria. J Antimicrob Chemother., 41, 563-565.

Li, Y., Xie, Y.Y., Chen, R.X., Xu, H.Z., Zhang, G.J, Li, J.Z. and Li, X.M. (2009), Effects of combined treatment with sansanmycin and macrolides on Pseudomonas aeruginosa and formation of biofilm. Biomed. Environ. Sci., 22, 170-177. 
Lima, L.H.A. and Berlinck, C.N. (2003), Xilitol, o adoçante do futuro. Ciência Hoje, 33, 66-69.

Locatelli, C.I., Englert, G.E., Kwitko, S. and Simonetti, A.B. (2004), Aderência bacteriana in vitro a lentes intra-oculares de polimetilmetacrilato e de silicone. Arq Bras Oftalmol, 67, 241-248.

Ly, K.A., Riedy, C.A., Milgrom, P., Rothen, M., Roberts, M.C. and Zhou, L. (2008), Xylitol gummy bear snacks: a school-based randomized clinical trial. BMC Oral Health, 8, doi:10.1186/1472-6831-8-20, 11 pages.

Makinen, K.K. (2000), Can the pentitol-hexitol theory explain the clinical observations made with xylitol? Med. Hypoteses, 54, 603-613.

Mata, P.T.G. and Abegg, M.A. (2007), Descrição de caso de resistência a antibióticos por Pseudomonas aeruginosa. Arq Mudi., 11, 20-25.

Mussatto, S.I. and Roberto, I.C. (2002), Xilitol: Edulcorante com efeitos benéficos para a saúde humana. Rev Bras Cienc Farm., 38, 401-413.

Naaber, P., Letho, E., Salminen, S. and Mikelsaar, M. (1996), Inhibition of adhesion of Clostridium difficile to Caco-2 cells. FEMS Immunol Med Microbiol., 14, 205-209.

Nowakonsky, A.V. (2007), Vigilância laboratorial de bacteriemias por microrganismos Gram negativos em pacientes adultos internados no Hospital das Clínicas - UNICAMP no período de 2000-2004: Implicação do uso de antimicrobianos selecionados no perfil de resistência destes microrganismos. MSc Dissertation, State University of Campinas, Campinas - SP, Brazil.

Pereira, A.F.F., Silva, T.C., Caldana, M.L., Machado, M.A.A.M. and Buzalaf, M.A.R. (2009), Revisão de Literatura: Utilização do Xilitol para a Prevenção de Otite Média Aguda. Arq. Int. Otorrinolaringol., 13, 87-92.

Sajjan, U., Moreira, J., Liu, M., Humar, A., Chaparro, C., Forstner, J. and Keshayjee, S. (2004), A novel model to study bacterial adherence to the transplanted airway: Inhibition of Bukholderia cepacia adherence to human airway by dextran and xylitol. J Heart Lung Transplant., 12, 1382-1391.
Sharon, N. (2006), Carbohydrates as future antiadhesion drugs for infectious diseases. Biochim Biophys Acta, 1760, 527-537.

Silva, A.F. (2010), Avaliação in-vitro da atividade antimicrobiana e da propriedade antiaderente do xilitol. MSc Dissertation, Federal University of Juiz de Fora, Juiz de Fora - MG, Brazil.

Silva, A.F., Silva, S.S., Oliveira, M.G. and Raposo, N.R.B. (2010), Inibição in vitro da aderência de enteropatógenos pelo xilitol. Rev. Ciênc. Médicas e Biológicas, 9, 42-49.

Silva, A.F., Suzuki, E.Y., Ferreira, A.S., Oliveira, M.G., Silva, S.S. and Raposo, N.R.B. (2011), In vitro inhibition of adhesion of Escherichia coli strains by xylitol. Braz Arch Biol Technol, 54, 235-241.

Silva, D.D.V., Mancilha I.M., Silva, S.S. and Felipe, M.G.A. (2007), Improvement of biotechnological xylitol production by glucose during cultive of Candida guilliermondii in sugarcane bagasse hydrolysate. Braz Arch Biol Technol, 50, 207-215.

Söderling, E. and Hietala-Lenkkeri, A. (2010), Xylitol and erythitol decrease adherence of polysaccharideproducing oral streptococci. Curr. Microbiol., 60, 2529.

Stehling, E.G. (1999), Estudo comparativo dos fatores de virulência de Pseudomonas aeruginosa isoladas de fibrose cística e outras infecções. MSc Dissertation, State University of Campinas, Campinas - SP, Brazil.

Tapiainen, M.T., Kontiokari, T., Sammalkivi, L., Ikaheimo, I., Koskela, M. and Uhari, M. (2001), Effect of xylitol on growth of Streptococcus pneumoniae in the presence of fructose and sorbitol. Antimicrob. Agents Chemother., 45, 166-169.

Received: October 21, 2010; Revised: January 20, 2011; Accepted: July 22, 2011. 